\title{
TEHNOKRATSKA DISTOPIJA U NAUČNO-FANTASTIČNOJ KNJIŽEVNOSTI: „KAD MAŠINA STANE“ E. M. FORSTERA, „SUMRAK“ DŽ. V. KEMBELA (UPOREDNA PERSPEKTIVA)
}

\begin{abstract}
Ovaj rad proučava tehnokratske distopijske vizije u naučno-fantastičnoj književnosti ranog dvadesetog veka. Obuhvaćene su dve kratke priče: „Kad mašina stane“ E. M. Forstera i „Sumrak“ Dž. V. Kembela. Autor ovog rada zasebno predstavlja kritička tumačenja, najpre Forsterove, a zatim i Kembelove priče. Obuhvaćena su tumačenja nekolicine uspešnih proučavatelja rane naučne fantastike. Autor, takođe, pomenutim kritikama dodaje i vlastite poglede na dotična dva dela. Na kraju rada sledi zaključno poglavlje, u kojem se upoređuju Forsterova i Kembelova antiutopija. Ova uporedna perspektiva u prvi plan stavlja činjenicu da pomenuti književnici pripadaju pionirima tehnološke distopije. U ideološkom smislu, srž ovog rada čine uverenja zaštitnika životne sredine. Oni zagovaraju stav da bi, zarad opstanka ljudske vrste, bilo najbolje da se u temelje savremene civilizacije ponovo ugradi naturistička duhovnost drevnih pagana, jer su antropocentrična shvatanja uzrokovala ozbiljno zagađenje brojnih ekosistema. Na taj način, mogao bi se postići opšteprihvaćeni sistem vrednosti, koji ne bi odveć ugrožavao biosferu. Forster, veliki privrženik prirodne estetike, i Kembel, veliki pobornik naučnog napretka, relativizuju svoje poglede kako bi čitavom svetu poručili da samo umereni razvoj tehnologije može obezbediti opstanak ljudskog roda.
\end{abstract}

Ključne reči: filozofija, distopija, nauka, evolucija, ekologija, antropocentrično, mašina, estetski, duhovnost, tehnološki

\section{Uvod}

„Znanje je moćc،, govorio je Fransis Bejkon [Francis Bacon, 15611626], veliki britanski erudita renesansne epohe (Simpson). Ovaj svestrani mislilac smatra se utemeljivačem moderne ljudske civilizacije, zasnovane na praktičnoj primeni naučnih dostignuća. Naime, njegova ideja da cilj

gphwchamp@gmail.com, Alfa univerzitet, Palmira Toljatija 3, Beograd 
empirijskog istraživanja prirode jeste obezbeđivanje lagodnijeg života za sve ljude odredila je kurs kojim će se u potonjim vekovima neprestano kretati brod celokupnog ljudskog roda. Bejkonovo vizionarstvo dalo je suštinski podstrek procvatu naučne misli, isprva na evropskom kontinentu, a zatim i širom civilizovanog sveta. „Novi Mojsije“, kako je Bejkona nazivao engleski pesnik Abraham Kauli [Abraham Cowley, 1618-1667], podario je istoriji filozofije jednu od najčuvenijih antropocentričnih koncepcija svih vremena (Simpson). Jedan od osnovnih koncepata hrišćanske metafizike - verovanje da čovek, jedino biće stvoreno po liku Božjem, treba da bude gospodar Zemlje - podstakao je Bejkona, inače pobornika racionalizma, da zaključi kako ovladavanje prirodom putem nauke (,prirodne filozofije“") neminovno predstavlja sledeću etapu u pravolinijskom toku istorije.

Na temeljima bejkonizma, u drugoj polovini osamnaestog veka, nastala je industrijska revolucija. Vatov [James Watt, 1736-1819] izum parne mašine najavio je rađanje kapitalističkog društva, u kome će jedini kriterijumi uspešnosti biti brzina saobraćaja i visina robne potrošnje. Autorka Đergović-Joksimović, srpska proučavateljka utopije, smatra da sveopšta opčinjenost tehnologijom poslebejkonovskog Zapada ne predstavlja nikakav ideološki iskorak iz ustaljenog koloseka utopijske književne tradicije: „Zapravo, utopijski grad/ostrvo kao odraz neba na zemlji i mašina kao delo čoveka, uzeti zajedno, ukazuju na komplementarnost božanskog i čovečjeg poduhvata“" (Đergović-Joksimović, 2009: 89). Odnosno, kao što su helenski polubogovi junaštvom morali da zasluže večni boravak u Elizijumu i kao što su srednjovekovni sveci duhovnim podvižništvom stizali do Carstva nebeskog, tako je i čovek osamnaestog, a pogotovo devetnaestog veka, verovao da ga industrijalizacija vodi ka blaženstvu, i to ne nakon smrti, već još za života. Dakle, to što tehnologija u ovom periodu preuzima primat nimalo ne remeti uvreženu koncepciju utopijske misli, prema kojoj čovek, uz neizostavnu božansku pomoć, nakon velikog truda uspeva da dosegne raj.

Međutim, kao i svi prethodni pokušaji stvaranja utopije, i ovaj se na kraju izjalovio. Ali, još pre nego što je utopijski potencijal tehnološkog napretka u realnom svetu doživeo krah, među evropskim i američkim intelektualcima bilo je onih koje ideja o „bezgraničnoj moći“ mašina nije uspela da zavara. U devetnaestom veku, kao suprotnost tehnološkim utopijama materijalnog blagostanja E. B. Litona [Edward Bulwer Lytton, 18031873] i Edvarda Belamija [Edward Bellamy, 1850-1898], stoje antiindu- 
strijske utopije Samjuela Batlera [Samuel Butler, 1835-1902] i Vilijama Morisa [William Morris, 1834-1896] (Đergović-Joksimović, 2009: 97, 105). Otprilike tri veka nakon Bejkonovog uspostavljanja novog, naučno orijentisanog sistema znanja, Prvi svetski rat je gotovo u potpunosti raspršio čovekove nade da bi mašina možda napokon mogla da mitsko-religijsku idilu pretvori u stvarnost (2009: 140-141). Drugi svetski rat i upotreba sredstava masovnog uništenja učinili su da ljudski rod shvati da „nauka sama po sebi nije ni dobra ni zla, već da uvek od ljudi zavisi kako će naučna otkrića biti primenjena“ (2009: 141). Stoga, u dvadesetom veku, distopijske vizije visoko mehanizovane ljudske budućnosti postaju sve dominantnije, dok sve malobrojnije književne utopije imaju uglavnom ruralni karakter (2009: 141).

Jedan od prvih književnika (nakon Batlera i Morisa) koji je prorokovao ubrzani razvoj nauke, ali i sveopšte razočaranje u moć tehnologije, bio je Britanac Edvard Morgan Forster [Edward Morgan Forster, 1879-1970]. Njegovo jedino naučno-fantastično delo, kratka priča pod naslovom „Kad mašina stane“ („The Machine Stops“), predstavlja autorov pokušaj da svojim savremenicima predoči koliko destruktivno može biti prenaglašeno oslanjanje na tehnologiju. Nakon užasnih razaranja Prvog svetskog rata, među intelektualcima u Zapadnoj Evropi i Sjedinjenim Američkim Državama počelo je da raste nepoverenje prema tehnologiji. Jedan od najčuvenijih pisaca naučne fantastike u periodu između dva svetska rata bio je Amerikanac Džon Vud Kembel [John Wood Campbell, Jr. 1910-1971]. U kratkoj priči „Sumrak“ [,Twilight“], Kembel govori o tome koliko nepovoljan uticaj apsolutna mehanizacija može imati na ljudsku intelektualnu radoznalost.

Ovaj rad će imati za cilj da prikaže sličnosti i razlike između dva pomenuta velika ostvarenja rane naučne fantastike, književnog žanra koji će naprečac steći ogromnu popularnost a utopijsku književnost, kao podređenu, smestiti u svoj kolosalni tematski okvir. Premda je dvadeseti vek dokazao da nauka nije svemoćna, on je takođe pokazao da ideja o uvećanju ruralnih sredina, barem još uvek, nema dovoljno pristalica da bi se uspešno mogla sprovesti na globalnom nivou. Iako je, početkom sedamdesetih godina dvadesetog veka, ekologija, kao biološka disciplina, iznedrila prve pokrete za očuvanje životne sredine, ispostavilo se da su materijalističke ideje isuviše čvrsto ukorenjene među svetskim moćnicima, te ekološke političke kampanje ni danas ne uspevaju da zabeleže značajnije uspehe 
(Otto, 2006: 23). Zato će u ovom radu najpre biti zastupljena teorija savremene ekologije, prema kojoj čovek, kao po prirodi animalno biće, ni po koju cenu ne sme zanemarivati osnovne zakone Majke prirode. Osim stanovišta biološke nauke, ova komparativna perspektiva obuhvataće i elemente duhovnosti (pogotovo u slučaju Forsterove priče). Rad će se osvrnuti i na Forsterov filozofski relativizam, čiji je vesnik, Protagora iz

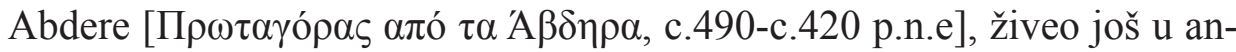
tičkoj Grčkoj. Takođe će biti pomena i o mogućim različitim tumačenjima Kembelove priče sa aspekta njegovog stava prema nezauzdanom razvoju tehnologije.

Nakon neuspeha svetskih političkih i pravnih institucija da spreče izbijanje Drugog svetskog rata, čak je i veliki pristalica tehnološkog razvoja, H. Dž. Vels [Herbert George Wells, 1866-1946], izgubio svaku nadu da čovečanstvo može naučiti da kontroliše svoje „unutrašnje demone“. Međutim, uprkos užasima svetskih ratova, ništa nije uspelo da spreči ubrzani tehnološki razvoj, koji i danas traje. Stotinak godina nakon što je Forster objavio pomenutu priču, svetskom mehanizacijom upravljaju kompjuteri. Odnosno, kraj dvadesetog i početak dvadesetprvog veka obeležava globalna digitalizacija (Anon). U svetu današnjice, sve češće se pojavljuje bolest zavisnosti od Interneta. Sve više ljudi zagovara tezu da kompjuterizacija škodi procesu socijalizacije, pa samim tim i razvoju dečjeg intelekta. To što se polako obistinjuju zloslutna predviđanja Forstera i Kembela o katastrofalnim posledicama tehnokratizacije čini njihove kratke priče posebno značajnim za sve mislioce koji predano rade na stvaranju bolje budućnosti za svekoliko čovečanstvo.

\section{Tumačenje Forsterove kratke priče „Kad mašina stane“}

Edvard Morgan Forster rođen je u viktorijanskoj Engleskoj. Duga vladavina kraljice Viktorije (1837-1901) ostala je upamćena kao vrhunac moći Britanske Imperije. Ovo je za Britaniju bio period ekonomskog blagostanja, zasnovanog na industrijalizaciji vlastitog ostrva i kolonijalnoj eksploataciji brojnih prekomorskih poseda. Odsustvo velikih ratova u Evropi (izuzev Francusko-pruskog rata iz 1871, u kome Britanija nije uzela učešća) bilo je bitan činilac za uspostavljanje privrednog prosperiteta. Ovaj period, poznat i kao Pax Britannica (Britanski mir), predstavljao je čudnovatu mešavinu velike pobožnosti i još većeg materijalizma. 
Forster je još kao student shvatio da poštovanje strogih društvenih normi viktorijanske Engleske neće zadovoljiti njegove duhovne potrebe. Poput nekih svojih znamenitih savremenika, i Forster je tragao za nečim uzvišenijim u odnosu na uglavnom licemernu, puko formalnu religioznost svojih sugrađana. Zato je, u bogatim riznicama stare helenske filozofije i orijentalnog misticizma, pronašao odgovarajuće utočište za svoj nemirni duh (Jonsson, 2012: 162). Međutim, Forsteru je, od isprazne duhovne atmosfere, možda još više smetala bezobzirna industrijalizacija Engleske na štetu njenog bogatog zelenila. Upravo je u priči „Kad mašina stane“ najbolje prikazana Forsterova filozofski utemeljena svest o čovekovoj nerazdvojivosti od njegovog iskonskog okruženja - prirode. Sledeći pasus iz Forsterovog dnevnika jasno ukazuje na to kakva su razmišljanja podstakla tvorca prve tehnološke distopije u dvadesetom veku (kako ga je 1967. okvalifikovao kritičar Mark Hilegas) da napiše ovu priču:

Dana 27. januara 1908: Prošlog ponedeljka jedan čovek, po imenu Farman, obleteo je krug od preko jednog kilometra u obimu za minut i po. Nauka napreduje brzo i, ako doživim starost, dočekaću da vidim kako na nebu vlada isto tako velika gužva kao i na drumovima. Ovo zaista jeste jedna nova civilizacija. Rodio sam se pri kraju epohe mira, a sada ne mogu da osećam ništa drugo do očaja. Umesto da nauka oslobodi čoveka - a Grci zamalo da u tome uspeju istančanim osećajem za umerenost - ona od njega čini roba u službi mašina. Podela na različite nacije će nestati, ali bratstvo svekolikog čovečanstva neće doći. Bez sumnje, krilatica naših predaka: „Slat-

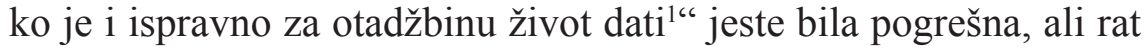
budućih vremena neće biti zaodenut $u$ varljivo ruho lepote ili ideološkog sukoba. Gospode, kakvi izgledi za budućnost! Kućice na koje sam navikao biće zbrisane, vazduh će zaudarati na benzin, a letelice će rasparčati zvezdano nebo. Možda će čovek dobiti novu, čak i veću dušu za novonastale uslove. Međutim, takva duša, kao što je moja, biće ubijena (Anon).

1 'Dulce et decorum est pro patria mori.' Izreka iz Horacijevih Oda (Druga knjiga). Prevod na srpski urađen po engleskom prevodu, dostupnom u izvoru koji je naveden na začelju citiranog odlomka. 
Navedena dnevnička zabeleška jasno ukazuje na to da je Forsterova duhovnost bila usko povezana sa ontološkim shvatanjima paganskih, takozvanih ,prirodnih“ religija. Za većinu drevnih animističkih religija karakteristično je verovanje da duhovi bogova počivaju u telima životinja, kao i u raznim prirodnim sredinama (u šumama, jezerima, rekama, morima, planinama, itd). Čak i oni, uslovno rečeno, napredniji oblici paganizma, koji su se odlikovali antropomorfizacijom božanstava, neizostavno su obuhvatali verovanje da i elementi životinjske telesnosti imaju udela u morfologiji besmrtnih bogova, koji takođe obitavaju u prirodi. Dakle, drevno mnogoboštvo nije pravilo tako upadljiv kontrast između prirodne telesnosti i transcendentalne duhovnosti, kao što to čine velike jednobožačke religije. Štaviše, politeisti starog veka nisu smatrali ni da je ispitivanje empirijski saznatljivog u potpunosti nepodudarno sa duhovnom metafizikom, na čemu insistira nauka, suvereni gospodar savremenog sistema znanja. Stoga, kada se u obzir uzme epistemološka isključivost pozne viktorijanske epohe, ne treba da čudi to što je Forstera zanimao hinduizam, jedina velika mnogobožačka religija današnjice čije je centralno verovanje utemeljeno na konceptu reinkarnacije ${ }^{2}$. S druge strane, kada se u obzir uzme kruta viktorijanska etika, nije iznenađujuće ni Forsterovo interesovanje za misli helenskih filozofa, jer su oni osporavali uvreženu mitološku kosmogoniju grčkih polisa, ali su u isti mah skromno dopuštali mogućnost da možda ni njihovi filozofski pogledi ne pružaju apsolutnu istinu.

U priči „Kad mašina stane“, Forster opisuje svoju viziju ljudske rase iz daleke budućnosti. Već na samom početku ove trodelne pripovetke, čitalac saznaje da svaki stanovnik ove civilizacije živi sam ,u jednoj malenoj sobi, šestougaonog oblika, nalik na ćeliju u pčelinjem saću“ (Forster, 1909: 1). Svaka od ćelija opremljena je aparaturom, koja ljude snabdeva svim onim što je potrebno za srećan život, a ta aparatura pokreće se jednostavnim pritiskom na određeno dugme. Ova civilizacija obitava pod zemljom. Nju su stvorili ljudi, koji su sanjali o savršenom svetu - svetu bez bolesti, ratova i bilo kakvih drugih ugrožavajućih faktora za čovekovu sigurnost. Utopijska zamisao ovih vizionara sprovedena je u delo stvaranjem svemoćne Mašine [The Machine], koja je čoveku konačno uspela da

2 „Verovanje da se čovek posle smrti može ponovo roditi kao neka druga osoba, životinja ili stvar“ (Shovel, 2007: 1250). Autor ovog rada ukazuje na to da su, prema hinduizmu, sva živa bića bogovima podjednako draga. To objašnjava Forsterov sistem vrednosti, koji pomiruje naučni evolucionizam i duhovnost. 
omogući ono što je on oduvek želeo - egzistencijalnu sigurnost, potpunu udobnost i savršene uslove za intelektualno napredovanje.

Međutim, ironičan način na koji Forster opisuje svakodnevni život ovih ljudi jasno ukazuje na to da je sistematskom mehanizacijom čovek mnogo više izgubio nego što je dobio. Naime, prvi razgovor između Vašti i njenog mladog sina Kuna govori o jednoličnosti i bezosećajnosti ovih mehanizovanih jedinki (to se u carstvu Mašine ne odnosi jedino na Kuna). Jer, kada Kuno zatraži od majke da ga poseti (Vašti živi ispod Novog Zelanda, dok se nad Kunovim stanom prostire engleska pokrajina Veseks), Vašti odgovara kako nema vremena za dvodnevni let: „Ne dopadaju mi se ni grozna tamna zemlja, ni more, niti zvezde kad padne noć. U letelici mi se ne javljaju nikakve ideje“ (Forster, 1909: 2). U ovim Vaštinim rečima sadržana je ponižavajuća samoobmana mašinske civilizacije, jer su njeni ljudi uvereni da ih neinventivni razgovori o davno proizvedenim idejama vode ka duhovnom prosvetljenju. Ovu mislilačku ustajalost najbolje oslikava govor jednog cenjenog filozofa pri kraju priče, nakon što Kunovo „svetogrđe“" podstakne sveopštu uzbunu među braniteljima postojećeg poretka, zasnovanog na neprikosnovenom autoritetu „nepogrešive“ Mašine. Govor upućen poslušnim građanima započinje anatemizacijom originalnih ideja: „Čuvajte se ideja koje se stiču iz ličnog iskustva“ [...] „,Takve ideje zapravo ne postoje. One nisu ništa drugo do fizičkih utisaka koji proizilaze iz ljubavi i straha, a ko bi mogao da izgradi filozofiju na jednom tako besmislenom temelju? Neka vaše ideje dolaze iz druge ruke, a, ako je moguće, i iz desete ruke, jer će tada one biti sasvim bezbedne od tog uznemiravajućeg elementa, koji se zove 'neposredno posmatranje"“ (Forster, 1909: 18). U nastavku, ovaj besednik na primeru istorijskog razvoja kritike o Francuskoj buržoaskoj revoluciji navodi zašto navedeni obrazac mislilaštva ima neprocenjivu vrednost: „I vremenom“ - ton mu je postao viši - „stići će pokolenje koje će uspeti da se izdigne iznad činjenica, iznad utisaka, pokolenje koje je sasvim bezbojno, ljudi serafimski čisti od kala ličnosti, koji na Francusku revoluciju neće gledati onako kako se ona odigrala, niti onako kako bi oni želeli da se Revolucija odigrala, već onako kako bi se ona odigrala da se desila u vremenu Mašine“ (Forster, 1909: 19). Dakle, samo slepa poslušnost „,svemoćnoj“, a zapravo totalitarnoj Mašini može ljudskom rodu održavati stanje nepomućene sreće.

Međutim, u ovoj tehnološki naprednoj civilizaciji, samo jedan glas remeti istomišljeništvo. Taj glas pripada Kunu, koji, slično autoru ove pri- 
če, od života želi mnogo više nego što mu nudi podzemni svet tehnološkog blagostanja. Kuno je opčinjen zvezdanim nebom. Smeta mu monotona inertnost svakodnevice. Niti želi da majku vidi niti da sa njom razgovara preko monitora, „kroz dosadnu Mašinu“ (Forster, 1909: 2). Ne podnosi veštačku hranu, a ni veštačko milozvučje svoje ćelije. Predavanja sluša zato što ga priče o nekadašnjem čovečanstvu nadahnjuju, a ne, kao svi ostali, zbog toga što je učestvovanje u tim događajima društveno prihvatljivo i, $u$ površnom smislu, interesantno. Dok iz letelice posmatra zvezde, sanjari o danima kada je Alfred, saksonski kralj Veseksa, sa mačem u ruci, na travnatim brdima svoje grude, naterao danske osvajače u beg. Za Kuna priroda nije neprijatelj koga su ljudi uz pomoć tehnologije pokorili, a koji više nije vredan nikakvog intelektualnog udubljavanja. On, naprotiv, mašta o tome da bi jednog dana možda mogao da, poput svojih davnih predaka, čvrsto stane na zemlju i upre pogled ka visini, u lepotu beskrajnog zvedanog neba. Kuno se, za razliku od njegove majke, ne boji fizičkog kontakta. Njegov glas usamljeno odjekuje podzemnim galerijama mašinske civilizacije.

Nasuprot liku Kuna, Vašti predstavlja glas većine. Nju nimalo ne ushićuje pogled na zvezde. Dok letelicom putuje ka stanu svog sina, proživljava najneprijatnije trenutke u životu. Zračak izlazećeg sunca, koji se probija kroz oštećeni metalni kapak, na nju deluje veoma uznemirujuće. Dodir stjuardese, koja zatim pokušava da je pridrži da ne padne, samo još više pogoršava Vaštinu napetost. Međutim, i njen lik poseduje izvesnu osobenost. „Vašti u sebi nosi buntovničke impulse, koje ne može da pomiri sa svojim svesnim ubeđenjima“ (Jonsson, 2012: 164). Naime, po mišljenju Emeli Jonson [Emelie Jonsson], Kunova majka je, duboko u sebi, pomalo nezadovoljna time što nije dopušteno crpiti ideje iz direktnog iskustva van sopstvene ćelije (2012: 164). Kao dokaz za ovakvu tvrdnju, Jonsonova prvo navodi činjenicu da se, posle prvog digitalnog razgovora sa Kunom, Vašti spontano javlja osećaj da je njen sin neveseo (iako monitor ne prenosi precizan izraz lica) (2012: 164). Zatim, autorka tvrdi da Vaštine misli, iskazane posredstvom naratora, a koje glase: , [...] ima nečeg posebnog u Kunu - bilo je nečeg posebnog kod sve njene dece" govore o majčinoj, doduše nedovoljno snažnoj, naklonjenosti prema sinu (2012: 164). Međutim, iako pomalo različita od drugih, nju povremeni osećaj blage nesigurnosti neće, kao Kuna, moći da podstakne na buntovna dela.

Iz prethodno rečenog, proizilazi zaključak da je Forsterova mašinska civilizacija, čije poglede zastupa Vašti, ,,antipesnička, antifilozofska i an- 
tiljudska“" (2012: 167). S druge strane, Kuno, koji uspeva da ostvari svoju zamisao i izađe na površinu Zemlje, ima ulogu tragičnog, prometejskog heroja, koji daje sve od sebe zarad duhovnog i telesnog oslobođenja čovečanstva i, uprkos velikom trudu, ne postiže krajnji cilj.

Kuno, dakle, najzad uspeva da, makar samome sebi, dokaže kako Mašina nije nikakav sveprožimajući entitet. Našavši se na površini, van delokruga Mašine, biva veoma iznenađen činjenicom da po prvi put u životu ne čuje brujanje metalnog gospodara. Ovim smelim poduhvatom, Kuno uspeva da dokaže još nešto, a to „nešto“ jeste činjenica da je, uz veliki napor, moguće opstati na spoljašnjem „nečistom“ vazduhu. Do ovog drugog dokaza glavni junak dolazi nakon što ugleda, ili mu se bar tako učinilo, ljudska bića na površini Zemljine kore. Kada crvoliki Aparat Popravljač [The Mending Apparatus] počne da ga povlači natrag u podzemlje, Kuno, nalik Spartancima iz Termopila, stoički odlučuje da se svojom nevelikom telesnom snagom do poslednjeg daha suprotstavlja silnom neprijatelju. Ovoga puta, David ne uspeva da pobedi Golijata, i Kuno se, povrativši svest, budi u svojoj staroj sumornoj sobi.

Ovde je od velike važnosti istaći misao, koja je Kunu, u trenutku najvećeg straha, ulila presudnu kap srčanosti, i zbog koje nije odustao od namere da pokida stege svog protivčovečanskog društva. U pitanju je geslo: „Čovek je mera“ (Forster, 1909: 12). Ova izreka potiče od već pomenutog Protagore iz Abdere. U izvornom značenju, ona se zajedno sa drugom poznatom Protagorinom izrekom odnosila na epistemološki i etički relativizam $^{3}$. Kada je reč o sveukupnom Forsterovom opusu, može se govoriti o obema navedenim vrstama relativizma. Međutim, u slučaju priče „Kad mašina stane", dotična krilatica ima jasno određenu funkciju. Tu funkciju bi bilo najbolje opisati kao udar na bezrezervno poverenje u moć tehnologije. U širem smislu, stav o merodavnosti čoveka mogao bi se primeniti i na viđenje da je svaka vrsta totalitarizma ogroman greh prema ljudskoj prirodi. Pojam ljudske prirode trebalo bi posmatrati sa aspekta Darvinove [Charles Darwin, 1809-1882] Teorije o evoluciji (1859), ali i sa stanovišta Forsterove

3 Dve Protagorine izjave na koje se aludira u celosti glase: 1) „Čovek je mera svih stvari, onih koje jesu da jesu, onih koje nisu da nisu.“ i 2) „O bogovima ne mogu saznati ništa - niti da li postoje, niti kavi bi mogli biti. Mnogo toga me u tome sprečava - na primer, nejasnoća same stvari i kratkoća ljudskog života“. Ove mudrosti jesu pokazatelj Progatorinog agnosticizma, odnosno epistemološkog relativizma (Poster). 
prirodnjačke duhovnosti. Stoga će u nastavku biti reči o isprepletanosti naučnih i duhovnih shvatanja pripovetke „Kad mašina stane“.

Kao što je ranije navedeno, Kuno je po svojoj prirodi atipičan stanovnik „utopijskog“ podzemlja. Njegova posebnost može se pripisati činjenici da je njega „milosrdna“" Mašina poštedela na rođenju, dopustivši mu da živi, iako je društveni običaj da se svako novorođenče, koje pokazuje telesnu živahnost, odmah podvrgne eutanaziji:

U danima Mašine, mišićavost je postala mana. Sve bebe su na rođenju pregledali, a svaka koja je obećavala prekomernu snagu bila bi uništena. Humanitarci će možda protestovati, ali ostaviti atletu u životu zaista ne bi bilo nikakvo dobro delo. On nikada ne bi bio srećan u životnim uslovima koje je stvorila Mašina. Takva osoba bi čeznula da se penje na drveće, da se kupa u rekama, da svoju snagu odmerava naspram brda. Čovek se mora prilagoditi svojoj sredini, zar ne? U osvit civilizacije naši se slabići moraju bacati u podnožje planine Tajget, a u sumrak čovečanstva naši će snagatori dobiti eutanaziju, kako bi Mašina mogla da napreduje, kako bi Mašina mogla da napreduje, kako bi Mašina večno mogla da napreduje (Forster, 1909: 11).

Forsterovo ironično ponavljanje na kraju ovog odlomka ukazuje na ugnjetački karakter Mašine, neživog gospodara živih ljudi. Međutim, za evolucionističku kritiku, najveći značaj ima to što Forster pominje prilagođavanje sredini. Jonsonova smatra da se, sa aspekta teorije evolucije, u kontrastu između spartanske i mašinske eugenike može uočiti velika zabluda mašinske civilizacije. Naime, iako oba navedena eugenička obrasca jesu vrste veštačke a ne prirodne selekcije, mašinska eugenika predstavlja ozbiljniju logičku pogrešku, jer Mašina, za razliku od antičke Sparte, ljude primorava da se putem veštačke selekcije prilagode samo jednoj, i to nevelikoj i nepouzdanoj biološkoj niši (Jonsson, 2012: 171-172). Dakle, ako je suditi po darvinističkim kriterijumima, ljudi mašinske civilizacije osuđeni su na propast zbog toga što je njihova adaptacija usmerena na jednu veštačku, usku nišu, umesto da nastoje da se prilagode najširem biološkom pojmu koji omogućava život - prirodi.

Postoji još jedan odlomak koji govori o pogrešnim shvatanjima evolucije među žiteljima mehanizovanog podzemlja. U tom odlomku, Forster 
kroz tugovanje svojih junaka iznosi svoj stav prema čovekovoj zavisnosti od tehnoloških tvorevina:

Plakali su zbog čovečanstva, njih dvoje, a ne zbog sebe samih. Nisu mogli da podnesu da je došao kraj. Pre nego što je nastala tišina, otvorili su svoja srca i sada su znali šta je na zemlji važno. Čovek, kruna sveukupnog živog sveta, najplemenitiji od svih vidljivih bića, čovek koji je nekada davno načinio boga po svom liku, a svoju snagu ogledao spram zvezdanih sazvežđa; čovek, predivan u svojoj nagoti, umirao je, a ugušilo ga je ruho koje je sam sebi ispleo. Nakon mnogo vekova trudbeništva, ovo je bila njegova nagrada. Uistinu, to ruho se na početku činilo božanstvenim, ukrašeno nijansama kulture, zašiveno nitima samoodricanja. I božanstveno je zaista bilo, sve dok je čovek mogao da ga skine kad god poželi i da živi sopstvenom suštinom, koja se zove duša, i drugom suštinom, podjednako božanskom, koja jeste telo. Greh prema telu - to je glavni razlog zbog kojeg su plakali; vekovi sagrešenja prema mišićima i nervima, i prema tih petoro vrata kroz koja nam dolazi sve što možemo da razumemo - sve je to zataškavano pričom o evoluciji, dok im tela nisu postala bela kaša, stecište za ideje koje su podjednako bezbojne, poslednji uzaludni trzaji jednog duha, koji je nekad davno dosegao zvezde (Forster, 1909: 24-25).

Dakle, Forster smatra da je svaki pokušaj izveštačenja čoveka neprirodan, a samim tim veoma opasan. Jednostavno, čovek je samo životinja, doduše, uzvišena životinja sa sposobnošću duhovnosti. Zato će, poručuje Forster, biti veoma pogubno ako čovek nastavi da se samoobmanjuje verovanjem da ga tehnologizacija može učiniti moćnijim od prirodnih evolucionih zakona.

Prethodni odlomak sadrži reči neimenovanog naratora, za koga nema sumnje da predstavlja glas samog Forstera. Ovo tugovanje Kuna i Vašti nad tragičnom sudbinom čovečanstva nastupa na samom kraju priče, nakon što Mašina nepovratno prestane da radi, a nekoliko trenutaka pre nego što se jedna letelica nekontrolisano sunovrati i svojim oštrim čelikom pošalje poslednja dva ljudska bića pod zemljom u smrt. Međutim, dvoje glavnih junaka uspevaju da pronađu duhovni spas, makar i na svega neko- 
liko časaka. Zagrljeni i suznih očiju, majka i sin nalaze utehu u Kunovoj uverenosti da je u toku svog kratkotrajnog boravka na površini ugledao ljudska bića, te da će, ipak, ostati šačica ljudi, koji će, poučeni katastrofom podzemne civilizacije, uspeti da povrate pun sjaj i dostojanstvo slobodnog, sopstvene telesnosti svesnog, čoveka. Moralna pobeda i duhovno prosvetljenje umirućih protagonista sadržani su u sledećim rečima hrabrog Kuna: „Vratili smo se onome što jesmo. Umiremo, ali se ponovo osećamo živim, baš kao što su se osećali ljudi u Veseksu, kada je Alfred isterao Dance. Sada znamo ono što znaju ljudi napolju, oni koji žive u oblaku boje bisera“" (Forster, 1909: 25). Iz Kunove „neortodoksne“ oduševljenosti telesnošću, zvezdama, zelenim brdima, maglom boje bisera i hrabrošću saksonskih ratnika mogu se izvući zaključci o Forsterovim duhovnim pogledima.

Iza sličnosti Forsterovih shvatanja sa orijentalnim duhovnim koncepcijama krije se činjenica da je duhovnost ovog pisca u velikoj meri bila zasnovana na estetizmu. U tom smislu, ne bi bilo pogrešno reći da umirući Kuno, koji spokojstvo nalazi u tome što ljubi svoju majku, gleda je i sa njom razgovara bez posredovanja Mašine, liči na nekakvog samuraja koji, usred krvavog bojnog polja, umire srećan, jer mu se čini da u daljini vidi trešnjin cvet savršenog oblika ${ }^{4}$. Dakle, Forsterova duhovnost, koja počiva na ubeđenju da čovek treba da bude zadovoljan malim, od prirode dobijenim, darovima, pojavljuje se kao antipod duhu ranog dvadesetog veka, koji je bio prožet eksploatatorskom nezajažljivošću materijalistički orijentisane većine.

Kunov buntovni lik, koji u osnovi podražava ličnost Forstera, ogleda se u njegovom nezadovoljstvu etabliranim društvenim sistemom. To nezadovoljstvo pisac dirljivo ilustruje u sledećem patetičnom Kunovom protestu:

Zar ne vidite, zar niko od vas predavača ne vidi da smo mi ti koji umiru, a da ovde dole zapravo živi jedino Mašina? Stvorili smo Mašinu da čini našu volju, ali sada ne možemo da je nateramo da čini našu volju. Ona nas je lišila osećaja za prostor i osećaja za

4 Izuzetno upečatljiva scena, puna uzvišenog patosa, iz čuvenog filmskog ostvarenja reditelja Edvarda Zvika [Edward Zwick], pod naslovom Poslednji samuraj [The Last Samurai]. Ovaj film iz 2003. predstavlja fiktivnu i idealizovanu obradu japanskog istorijskog razdoblja, poznatog kao „Restauracija carevine“. Pomenuti period iz šezdesetih i sedamdesetih godina devetnaestog veka označio je kraj „Ere šoguna" i početak modernizacije u Japanu. 
dodir, učinila je da svi ljudski odnosi izblede, svela je ljubav na čin polnog odnosa, paralisala nam telo i volju, a sada nas primorava da je obožavamo. Mašina se razvija, ali ne zbog nas. Mašina nastavlja, ali ne radi nas. Mi postojimo samo kao krvna zrnca koja teku njenim arterijama i, kad bi mogla da funkcioniše bez nas, pustila bi nas da izumremo (Forster, 1909: 15).

U kontekstu Kunovog nezadovoljstva opšteprihvaćenim vrednostima, zanimljiv je pogled jednog budističkog teologa. Taj teolog smatra da je Forster (premda nije pripadao nijednoj konvencionalnoj religiji) barem nesvesno simpatisao budizam, i to najpre zbog toga što je njegova filozofija, utemeljena na neprestanoj potrazi za višim duhovnim vrednostima, $u$ svojoj suštini antropocentrična, a ne teocentrična (Abhaya).

Takođe je, sa aspekta duhovnosti, zanimljiv element čvrstog verskog dogmatizma u sledećem odlomku iz priče:

„Mašina“, uzvikivali su, „hrani nas, oblači i obezbeđuje nam dom. Kroz nju razgovaramo, kroz nju se vidimo, u njoj postojimo. Mašina je prijatelj ideja, a neprijatelj sujeverja. Mašina je svemoćna i večna. Blagoslovena neka je Mašina.“ Ubrzo je ovaj misaoni novitet odštampan na prvoj strani Knjige, a u narednim izdanjima ovaj ritual je prerastao u nekakav složeni sistem slavljenja i molitve. Reč „religija“ vešto je izbegavana, a Mašina je u teoriji još uvek bila nešto što je čovek stvorio i uveo u društvo, ali u praksi su je svi, izuzev nekolicine primitivaca, poštovali kao božanstvo. A nije bila poštovana jednoobrazno. Jedan vernik je uglavnom bio oduševljen plavim optičkim ekranima, preko kojih je video ostale vernike; drugi se divio aparatima popravljačima, koje grešni Kuno beše uporedio sa crvima; treći je uznosio liftove, a četvrti Knjigu. I svako se molio ovom ili onom predmetu i preklinjao ga da moli Mašinu, kao glavno božanstvo, za blagostanje. Progonstvo - i to je bilo prisutno. Nije došlo do primene toga iz razloga koji će uskoro biti predstavljeni. Ali, bilo je prikriveno i svi oni koji nisu prihvatali minimalni stepen vere, poznate kao ,univerzalni Mehanizam“, bili su u opasnosti od Beskućništva, što, kao što znamo, znači smrt (Forster, 1909: 19-20). Prisustvo svete knjige sa ulogom dokaza o pravovernosti, zatim, raz- 
granavanje kulta Mašine na veći broj podkultova, a na kraju i nagoveštaj inkvizicijskog progona jeretika, umnogome podsećaju na istorijska dešavanja u okviru hrišćanskih crkava. Ovo navodi na pomisao da je Forster možda želeo da ismeje hrišćanstvo. Međutim, kada, nakon Kunovog ,jeretičkog“ podviga, Vašti pokuša da svom sinu objasni kako je progon na površinu dokaz o milostivosti Mašine, mladi buntovnik odgovara kao mu je draža milost Božja. Kada se prethodna scena ima u vidu, može se reći da je ipak verovatnije da je Forster, pre nego hrišćanstvo, nameravao da ruglu izvrne svaku vrstu dogmatske i totalitarističke zaslepljenosti, a pogotovo onu koja se zasniva na bespogovornoj veri u moć tehnologije.

$\mathrm{Na}$ kraju, valja se osvrnuti na momenat u kome Kuno ističe šta mu je pomoglo da nadjača malodušnost, dok se napinjao da probije načeto ventilaciono okno: „Učinilo mi se da čujem duhove mrtvih radnika koji su se svake večeri vraćali svetlucavim zvezdama i svojim ženama, a sva pokolenja koja su živela na otvorenom prostoru dozivala su me - 'Uspećeš, hoćeš, stići ćeš do nas"“ (Forster, 1909: 12). Komentar Jonsonove na ovu scenu glasi da se svetlucave zvezde, voljene osobe i otvoreni prostor u jezik evolucionističke psihologije mogu prevesti kao stimulišući prirodni elementi, određene seksualne i emocionalne veze, i neograničena mogućnost prostornog kretanja (Jonsson, 2012: 168). Ovakav pogled možda najbolje oslikava isprepletanost naučne (evolucionističke) i duhovne (estetske) kritike ove Forsterove priče.

U obrađenoj priči jasno je uočljiva velika širina piščevih vidika, $s$ tim što je naglasak stavljen na to koliko ozbiljnu štetu neograničena tehnologizacija u budućnosti može naneti ljudskoj duhovnosti, odnosno duševnosti.

\section{Tumačenje Kembelove kratke priče „Sumrak“}

Sa aspekta utopijske književnosti, Kembelov „Sumrak“ se, kao i „Kad mašina stane“, može svrstati u pionirska dela tehnološke distopije. Razlog za ovakvu klasifikaciju leži u činjenici da je tek nakon Drugog svetskog rata ogromna većina književnika i književnica svu svoju pažnju usredsredila na kritiku socijalne nepravde širom sveta. U drugoj polovini dvadesetog veka, oštre kritike iz pera velikih pisaca nisu zaobišle nijedan oblik globalnog ugnjetavanja: ni komunistički totalitarizam, ni kapitali- 
stički konzumerizam, ni obespravljeni položaj žena, kao ni postkolonijalnu eksploataciju „zemalja Trećeg sveta“. Dakle, nakon 1945. godine nastupa period apsolutne dominacije distopijskih vizija u svetskoj književnosti.

Međutim, kada je reč o književnom opusu Dž. V. Kembela (koji u celosti pripada žanru naučne fantastike), pripovetka „Sumrak“ predstavlja zanimljivu atipičnost. Naime, Kembel svoju slavu nije stekao kao pisac, već prvenstveno kao urednik čuvenog časopisa Astounding. Ovaj časopis, koji je kasnije promenio naziv u Analog Science Fiction, bio je najuticajniji izvor naučno-fantastične književnosti od 1937. do ranih pedesetih godina prošlog veka (D’Ammassa, 2005: 69-70). Pomenuti period poznat je pod nazivom Zlatno doba naučne fantastike [the Golden Age of SF]. Ovaj termin podrazumeva da su mnoga od najpopularnijih naučno-fantastičnih dela nastala baš u ovom periodu, a Amerikanac Kembel smatra se ličnošću koja je započela, ali i obeležila ovo razdoblje. U toku ovih petnaestak godina, Astounding je uglavnom objavljivao kratke priče koje su nailazile na odobravanje urednika Kembela. Takve su priče najčešće bile dela „tvrde naučne fantastike“ [,Hard SF“], takozvane „,svemirske sapunice“, u kojima muški protagonisti, nakon uzbudljive kosmičke avanture, na kraju uvek uspevaju da putem izvanrednih tehnoloških postignuća nadmudre svoje neprijatelje, vanzemaljce (Roberts, 2006: 195). Inače, Adam Roberts [Adam Roberts] u svojoj Istoriji naučne fantastike [The History of Science Fiction] ističe da su od četrdesetih godina dvadesetog veka počela da se pojavljuju i dela koja su umerenom ideološkom opzicijom činila protivtežu Kembelovom idealu tehnološkog antropocentrizma (2006: 196). Jedno od takvih dela poteklo je upravo od samog Kembela, i to još 1934. godine, u osvit Zlatnog doba. U pitanju je kratka priča „Sumrak“, koja poništava mogućnost da Kembel nikada nije razmišljao u duhu antropološkog pesimizma.

Za tumačenje pripovetke „Sumrak“ najveći značaj ima ekološka kritika, koja od sedamdesetih godina dvadesetog veka počinje da dobija sve istaknutije mesto u krugovima intelektualaca. Doktorska disertacija Amerikanca Erika Ota [Eric Otto], pod naslovom Naučna fantastika i ekološka savest [Science Fiction and the Ecological Conscience], ukazuje na to koliko je svest o nezamenljivosti Zemljine biosfere prisutna u naučno-fantastičnoj književnosti. Dr Oto polazi od teze da ,se duhovnost i ekologija međusobno uklapaju, pri čemu prvi pojam drugome daje moralnu dimen- 
ziju, a to od sveta prirode - celine, sastavljene od međuzavisnih komponenata - čini nešto što za ljude predstavlja više od nekakvog količinski odredivog skladišta, čija bogatstva služe samo za rekreaciju i ekonomsku eksploataciju“ (Otto, 2006: 9). Dakle, kao kod Forstera, i ovde je posredi shvatanje da pradavni kultovi, vezani za Majku zemlju (vrhovnu boginju), savršeno odgovaraju evolucionističkoj premisi da je čovek samo jedna od mnogobrojnih životinjskih vrsta na Zemlji. Iz ovoga sledi zaključak da, iako poseduje intelektualnu superiornost nad ostalim živim svetom, čovek nikako ne bi smeo da se oglušuje o ekološke zakone u prirodi.

Zatim, dr Oto ističe da naučna fantastika, kao žanr koji se oslanja na stvaranje novih svetova $\mathrm{u}$ kojima je fokus na podređenosti čoveka $\mathrm{u}$ odnosu na planetu, predstavlja idealan korpus za ekokritičke interpretacije (2006: 12-22). Oto tvrdi da ekstrapolacija i Suvinovo „kognitivno očuđavanje" piscima omogućavaju da aktuelne društvene probleme (među ostalima i uništavanje prirode) prikažu na jedan neobičan način, u nekom budućem svetu, ali iz ugla nezadovoljnog kritičara (2006: 12-22). Upravo na ovom, očuđavajućem posmatranju grešaka, počiva subverzivni karakter naučne fantastike. Jer, suštinska ideja ekologije, prema kojoj čovek neprestano mora osluškivati impulse svoje roditeljke prirode, iz temelja potresa uvrežene vrednosti dogmatskog antropocentrizma, kapitalističkog materijalizma i urbanističkog ekspanzionizma (2006: 27-28). Kembelov „Sumrak“ predstavlja jednu od ranijih naučno-fantastičnih vizija koje podrivaju oduševljenost tehnocentrizmom. Međutim, kao što će se uskoro videti, ova priča se može posmatrati i kao panegirik ideji o blagodetima tehnološkog napretka.

Pre nego što se otpočne sa tumačenjem Kembelovih poruka, potrebno je ukratko predstaviti narativni tok ove priče.

„Sumrak“ bi se najsažetije mogao opisati kao naučno-fantastična priča, u kojoj glavni junak iz godine 3059. putuje kroz vreme, te svojim precima iz 1932. govori o tome šta je video u civilizaciji, udaljenoj sedam miliona godina u budućnosti. Glavni junak zove se Ares Sen Kenlin. Priču o njegovim doživljajima pripoveda Džim Bendel, dok ga pažljivo sluša narator, koji govori u prvom licu.

Daleki potomci ljudskog roda, o kojima je reč, predstavljaju sliku čovečanstva na umoru. Naime, Bendel je od Kenlina saznao da je čovečanstvo, pokušavajući da stvori idealne uslove za život, sav svoj trud usmerilo na razvoj tehnologije. Tako su ljudi započeli sa preuređivanjem prirode. 
Najpre su počeli uništavati bakterije, viruse i insekte. Potom su istrebili sve životinje koje su se mogle hraniti ljudskim mesom. Iskorenili su i mnoge korove, pa zatim biljojede, a onda i većinu biljnih vrsta na Zemlji. Oko dva i po miliona godina trebalo je ljudima da istrebe sve mikroskopske organizme na planeti. Tada je i sintetička hrana morala da zameni prirodnu. U narednih hiljadu i po godina, uništeni su i svi oblici života u okeanima. Oko četiri miliona godina od Kenlinovog vremena, čovečanstvo je započelo doba pune zrelosti. Milion godina trajao je procvat civilizacije. Tada su ljudi naselili svaku planetu i svaki mesec Sunčevog sistema. Baš u ovom razdoblju, čovek je, zahvaljujući nezapamćenom napretku, izgubio potrebu i za svojim poslednjim životinjskim pratiocem - psom. Od 3059, prošlo je pet miliona godina, i tada je otpočeo dugi period civilizacijskog nazadovanja. U narednih dva miliona godina, čovek je izgubio ono što ga je nadahnjivalo tokom čitavog postojanja - duhovnu radoznalost. Ljudi nisu izgubili samo želju za istraživanjem, već su takođe zaboravili da objasne mehaničke principe na kojima su njihovi preci izgrađivali ,temelje“ za sigurnu budućnost. Ti „temelji“ postojali su još uvek među tim malobrojnim ljudima poslednjeg stepena evolucije. Ti „temelji“ nekada su bili poput ljudi, jer su umeli samostalno da razmišljaju. Međutim, kao što je ljudski instinkt ljubopitljivosti u sterilnom okruženju sam od sebe iščileo, kao što je, uostalom, ljudska reproduktivna sposobnost počela da se jalovi, tako su i ti ,temelji““ jednostavnim pritiskom na dugme izgubili svoju intelektualnu vitalnost. Ti ,temelji“ bili su, dakle, mašine - sklopovi metalnih poluga i šrafova, kojima je čovek nekada davno darovao život da bi mu služile. Međutim, budući da je njihov tvorac sada bespomoćno očekivao nestanak svoje vrste, trebalo je da mašine naslede čovekov položaj gospodara planete. Uvidevši to, Ares Sen Kenlin je uz pomoć jednog ljubaznog građanina San Friska (nekadašnji San Francisko) pokušao, a na kraju i uspeo da, unutar šest mašina, pokrene kompjuterske procese koji će jednog dana stvoriti mašinu sa umnom radoznalošću. A to će, Kenlin se nada, te mašine osposobiti da se vremenom nauče savladavanju entropijskih problema, što će na kraju obezbediti opstanak civilizacije. Pripovetka se završava mislima naratora koji otkriva da veruje u Kenlinovu priču, iako ju je čuo iz druge ruke, zato što ga na takvu pomisao navodi način na koji je Bendel, neposredni svedok priče, rekao da ne veruje u nju.

Prema dr Otu, može se govoriti o interpretativnom dualitetu ove Kembelove kratke priče. S jedne strane, postoje kritičari, poput Bruksa Len- 
dona i Džona Hantingtona, koji „Sumrak“ tumače u svetlu tehnološkog optimizma (Otto, 2006: 35). Njihovo mišljenje glasi da Kembel uopšte ne uzima u obzir moguće naličje tehnologizacije ${ }^{5}$, jer je ideja da bi mašine, tvorevine ljudskog intelekta, trebalo da naslede ljudsku rasu, u potpunosti saglasna sa verovanjem mnogih ljubitelja nauke da tehnologija može prevazići ono što čovek ne može - problem entropije (2006: 35). Sledeća Kembelova misao to vešto ilustruje: „Kad se Zemlja ohladi, a Sunce se ugasi, te mašine će nastaviti. Kada Zemlja počne da puca i da se urušava, te savršene, neumorne mašine pokušaće da je poprave“ (Campbell 1934: 28).

Dakle, ako se uzme u obzir stav savremene astrofizike, život na Zemlji će se svakako ugasiti, ako ni od čega drugog, onda usled promena na Suncu u okviru prirodnog životnog ciklusa ove zvezde. S tim u vezi, stav tehnoloških optimista po pitanju budućnosti bi izgledao ovako: Ako naša rasa već mora da nestane, zašto joj onda ne bismo obezbedili opstanak, makar i posredstvom veštačkih tekovina civilizacije? Međutim, problem ovakve logike leži u tome što je u poslednjih četvrt veka nauka došla do zaključka da nezauzdani razvoj tehnologije ozbiljno zagađuje biosferu, te da usled procesa globalnog zagrevanja uskoro može doći do osetnijih katastrofalnih reakcija naše planete. Ovde u žižu interesovanja stupa ekološka kritika. Ona smatra da u priči „Sumrak“ Kembel opisuje koliko će samodestruktivno čovek postupiti ukoliko nastavi da nadmeno eksploatiše prirodu. Po njihovom mišljenju, pisac poručuje da čovek treba razumno da prihvati činjenicu da je on samo jedan od mnogobrojnih organa koji sačinjavaju celovito telo ogromne Zemljine biosfere (Otto 2006: 36).

Zagovornici ekokritike potporu za svoju argumentaciju nalaze u zaključku Aresa Sen Kenlina da se, sudeći po jednoj mapi, izgled i raspored kontinenata gotovo uopšte nije promenio nakon sedam miliona godina: „Sedam ili čak sedamdeset miliona godina nije mnogo vremena za staru Majku Zemlju. Ona će možda još i uspeti da postepeno uruši te prekrasne mašinske gradove. Može ona da čeka sto miliona, pa i čitavu milijardu godina, pre nego što bude pobeđena" (Campbell 1934: 30). Kembelov lek-

5 O Kembelovoj veri u moć tehnologije govori sledeća žalopojka Aresa Sen Kenlina, koju ovaj protagonista izriče, nakon što shvati koliko su njegovi potomci intelektualno zaostali: „Možete li da razumete koliko mi je beznadežne skrhanosti donelo to spoznanje? Ja, koji volim nauku, koji u njoj vidim, tačnije, koji sam u njoj uvek video spasenje, uzdizanje čovečanstva, uočio sam da su te veličanstvene mašine, plod čovekove trijumfalne zrelosti, zaboravljene i nerazumljive“ (Campbell 1934: 38). 
sički izbor ukazuje na to da se, između osvajački nastrojenog, tehnološki orijentisanog čoveka i braniteljke, Majke prirode, vodi borba u kojoj ljudi nemaju velikih izgleda za pobedu.

Pored dalekosežnih razmišljanja o sudbini čovečanstva, u Kembelovom „Sumraku“ nisu izostavljeni ni elementi ljudske duševnosti. U ovom pogledu, interesantno je to što autor nekoliko puta naglašava samoću, koju, kako Kenlin kaže, osećaju stanovnici daleke budućnosti. Sterilizacija biosfere uticala je na to da žitelji te tehnocentrične civilizacije počnu da gube moć reprodukcije, da im se, uprkos ogromnoj veličini mozgova, skoro u celosti ugasi i kognitivna plodnost, a kao rezultat tih nedostataka, ali i istrebljenosti životinja, kod njih se razvila poražavajuća duševna hladnoća.

Zatim, zanimljiv je način na koji Kenlin opisuje opadanje intelektualne radoznalosti, dok se letelicom spušta ka okupljenim stanovnicima San Friska:

Jer, jedna jedina stvar koja čoveka beše učinila velikim napustila ga je. Dok sam, prilikom sletanja, gledao u njihova lica i oči, sve mi je bilo jasno. Gledali su me, zainteresovani za tog stranca čudnog izgleda - a onda su produžili svojim putem. Došli su da vide sletanje letelice. Znate, to je redak događaj. Ali, samo su me prijateljski pozdravljali. Nisu bili radoznali! Čovek je izgubio instinkt radoznalosti.

Ali ne u potpunosti! Čudili su se nad mašinama, čudili su se nad zvezdama. Ali ništa nisu preduzimali u vezi sa tim. Taj impuls još nije bio potpuno izgubljen, ali gotovo da jeste. Umirao je. Za šest kratkih meseci, koliko sam boravio kod njih, naučio sam više nego što su naučili oni za dve, ili čak, tri hiljade godina života među mašinama (Campbell 1934: 37-38).

Međutim, možda je još zanimljivija scena, u kojoj Bendel opisuje šta je osećao, dok mu je Kenlin pevao, najpre „Pesmu o čežnji“, a potom „Pesmu zaboravljenih sećanja“:

Običan čovek ne bi nikada mogao da smisli takve pesme. S njima nešto nije u redu. Kad je pevao tu pesmu, imala je isuviše 
tužnih molskih tonova. Osećao sam kako premeće misli u potrazi za nečim što je zaboravio, za nečim što je očajnički želeo da nađe - za nečim što zna da nije smeo da zaboravi - i osećao sam kako mu to večito izmiče. Dok je pevao, osećao sam kako se to sve više udaljava od njega. Osećao sam kako taj izbezumljeni tražilac pokušava da se priseti toga - toga nečega što će ga spasiti. Onda sam čuo kako mu se oteo jecaj, koji je odavao poraženost duha - i pesma se završila (Campbell 1934: 39-40).

Te pesme Kenlin je čuo na Neptunu, mračnoj planeti koju su žitelji tamošnje dekadentne civilizacije napuštali i vraćali se na skoro podjednako dekadentnu maticu, Zemlju. Čuvši prijatelja Bendela, kako pokušava da otpevuši „Pesmu zaboravljenih sećanja“, narator dotičnu izvedbu upoređuje sa zvukom ,srceparajućih krikova, svojstvenih nekim životinjama, koji zvuče gotovo isto kao ljudski krici“" (Campbell 1934: 40). Naposletku, narator pojašnjava simboliku ove pesme:

Ta pesma čini da osećate baš ono što pevač želi da osećate - jer ne radi se o tome da ona zvuči ljudski - ona jeste ljudska. Ona predstavlja suštinu poslednjeg poraza čovečanstva, tako ja pretpostavljam. Uvek vam bude žao momka koji izgubi, nakon što se žestoko borio. E, pa, sada možete osetiti kako se čitav ljudski rod žestoko bori - i gubi. A znate da ne može sebi da priušti poraz, jer nema pravo na popravni ispit (Campbell 1934: 40).

Vredi pomenuti i to da Kembel jednim konkretnim primerom najbolje prikazuje koliko se ljudska pohlepa za stvaranjem tehnološke utopije na koncu pokazala autodestruktivnom. U pitanju je činjenica da je čak i pas, čovekov najbolji prijatelj, izgubio mesto pod suncem. Ovu poslednju životinjsku vrstu na Zemlji ljudi su isprva poštedeli, jer su im mašinske trke, u kojima su psi upravljali mašinama, pričinjavale veliko zadovoljstvo. Pas je, naime, uporedo sa čovekom ostvarivao intelektualni napredak: „Čovek je tada počeo dosezati zrelost, a njegov životinjski prijatelj - prijatelj koji ga je pratio milion godina do tvog i mog vremena, i još četiri miliona godina do vremena čovekove rane zrelosti - beše postao inteligentniji“ (Campbell 1934: 36). Međutim, čak ni pas nije mogao pratiti čoveka do 
samog kraja, jer je epoha pune zrelosti čovečanstva toliko uznapredovala, da ljudima nikakav životinjski prijatelj više nije bio potreban, pa čak ni izuzetno inteligentni pas. Čovek je, dakle, ,sam sebi iskopao jamu“ time što je pokušao da prirodu prilagodi sebi. Međutim, sve što je postigao jeste podizanje visokih zidina, koje će ga ograđivati od ostalih živih bića. Takvo stremljenje savršenstvu završiće se čovekovom izolacijom od biosfere, odnosno samoutamničenjem, i končanim sumrakom civilizacije.

Samoća, jalova životna sredina, reproduktivna neplodnost i ugašeni pogledi bez ijednog plamena vizionarske radoznalosti jesu estetski pokazatelji da je ljudski rod došao u bezizlaznu situaciju. Ta bezizlazna situacija, u skladu sa zaključnim rečenicama prethodnog pasusa, ima oblik evolucionističkog ćorsokaka. U tom smislu, može se zaključiti da čovekov hod prema tehnocentričnoj utopiji u izvesnoj meri ima suprotan smer $\mathrm{u}$ odnosu na darvinistički koncept usložnjavanja života. Naime, činjenica da istrebljenje bilo kog oblika života uzrokuje poremećaj opšteg lanca ishrane (što kasnije dovodi do nestabilnosti biosfere) predstavlja prvi korak u uništavanju onoga što je Priroda stvarala milijardama godina. Ljudi u Kembelovoj priči najpre uništavaju kopnene organizme, kao i proste, jednoćelijske organizme u vazduhu. Nakon toga, na red dolazi „pročišćavanje“ vodenih površina. Potom izumire i pas, a na kraju, pored sve malobrojnijih ljudi, na Zemlji ostaju samo ukrasne biljke, koje su izazivale oduševljenje čak i pri kraju epohe pune zrelosti. Dakle, antievolucionistička aktivnost čoveka ide suprotnim smerom u odnosu na evolucionističku aktivnost planete Zemlje. Odnosno, čovek prvo uništava sve oblike života na kopnu, a potom odlučuje da isto uradi i u rekama, jezerima, morima i okeanima. To predstavlja obrnut redosled u odnosu na evolucioni razvoj života, koji je najpre nastao u vodi. Kembelov prikaz uništavanja prirode nije u potpunosti antievolucionistički, jer kada bi takav bio, onda bi čovek, poslednji izdanak evolucije, nestao prvi, a jednoćelijski organizmi bi bili poslednji živi „svedoci“ kataklizme.

Prostora za podudarnost ima i ako se sveopšte izumiranje tumači sa aspekta hrišćanske kosmogonije. Podudarnost koja se ima u vidu takođe se odnosi na činjenicu da izumiranje ide suprotnim smerom u odnosu na stvaranje. Samo što se ovde nestanak, prvo kopnenih, a zatim i vodenih oblika života može posmatrati kao skrnavljenje svete Božje tvorevine. Međutim, „izokrenuta podudarnost“ između Kembelovog „Sumraka“ i hrišćanske kosmogonije ide jedan korak dalje. Naime, u gradu Neva Siti (nekadašnji 
Nevada Siti), baš kao i u biblijskom Postanju, nalazi se jedan deo koji je pokriven gustinom zelenog i mirisnog ukrasnog bilja. Međutim, kao što miomirisni Edenski vrt, zbog praroditeljskog greha, naposletku ostaje lišen svog najvećeg bogastva - Adama i Eve, tako i zeleni vrt Neva Sitija, uzdignut nad preostalim delom grada, po završetku epohe zrelosti, ostaje bez čoveka i biva prepušten novom baštovanu, mašini. U ovom kontekstu, mogao bi se izvesti zaključak da ljudi daleke budućnosti nestaju sa lica zemlje jer njihov greh prema prirodi, čudesnoj Božjoj tvorevini, ujedno jeste i greh prema Bogu'.

Na kraju bi pažnju trebalo posvetiti Kenlinovim rečima koje svedoče o tome da Kembelu nije bio stran stav umerenosti prema tehnološkom napretku:

Muzika divljaka je odveć jednostavna da bi bila prekrasna, ali je dirljiva. Poludivljaci pišu muziku koja je predivno jednostavna $\mathrm{i}$ jednostavno predivna. Vaša najbolja muzika bila je delo vaših crnaca. Čim bi čuli muziku, crnci bi joj prepoznali dušu i pevali bi je onako kako bi je osećali. Polucivilizovani narodi pišu veličanstvenu muziku. Oni se ponose svojom muzikom i vode računa o tome da bude poznata kao veličanstvena. Muzika koju oni proizvode toliko je sjajna da joj nedostaje sklada.

Oduvek sam našu muziku smatrao dobrom. Ali, muzika koja je dopirala kroz vazduh bila je muzika trijumfa koju peva nekakva

6 Autor ovog rada jednostavno pokušava da dokaže da hrišćanska doktrina nije direktno odgovorna za bezobzirnu eksploataciju prirode. Iako se u Svetom pismu kaže da je čoveku dato da bude gospodar nad biljkama i životinjama, to ne znači da Biblija opravdava nasilje nad prirodom. Tačnije, hrišćanstvo, prema zemaljskim kriterijumima, jeste antropocentrično, ali je ono, u širem smislu, teocentrično, jer priznaje postojanje duhovne, nebeske sfere, koja je uzvišenija od čulno saznatljive, zemaljske. Najispravnije bi bilo smatrati da je materijalizam glavni vinovnik za zagađivanje životne sredine, jer je učenje Sina Božjeg o Carstvu nebeskom zapravo potpuno suprotno ideji da se priroda treba uništavati. Naprotiv, Hristos propoveda nebesko blaženstvo, do koga će stići oni koji shvate da je duhovno pretežnije od zemaljskog. Dakle, prema izvornom hrišćanskom učenju, sakupljanje zemaljskih bogatstava, koje suštinski počiva na čovekovom iskorišćavanju prirode, ne vodi Carstvu nebeskom. Zatim, čovekova pretežnost nad biljnim i životinjskim svetom zasniva se na krotkosti duha, a ne na intelektualnoj superiornosti. Carstvo duha i carstvo tela, u hrišćanskoj veri, naprosto predstavljaju dve suprotnosti. 
zrela rasa, čovečanstvo u punom sjaju pobede! To je čovek pevao o svojoj pobedi čudesnim zvukom koji me je očarao. Taj zvuk mi je pokazivao šta leži preda mnom. Nosio me je napred (Campbell 1934: 29-30).

U nastavku, Kenlin objašnjava da ta čudesna muzika govori o danima kada su ljudi vladali celim Sunčevim sistemom. To slavno vreme čovekovog trijumfa nad prirodom je, posle dva miliona godina, izgledalo kao nekakva bleda, neshvatljiva uspomena. Neva Siti je sada bio: ,grad usahlih ljudskih nada. Nisu to nade jedne rase, ni bele, ni žute, ni crne, već čitavog čovečanstva“" (Campbell 1934: 33).

Promišljanje o ovom delu pripovetke možda može iznedriti zaključak da, čak i ako mehanizacija, taj gorostasni simbol civilizovanosti, čovečanstvu uspe da donese savršen sklad, to ne znači da će ljudi time zaista postići sreću. Zapravo, postoji mogućnost da Kembel, slično Forsteru, želi da poruči kako čovek do sreće ne može stići ni ako potpuno odbaci tehnološke pronalaske, niti ako posegne za apsolutnom tehnologizacijom sveta. Utopija se možda može pronaći u apolonskoj umerenosti, tj. u starogrčkoj krilatici koja glasi: „Spoznaj sebe samoga“. Možda, dakle, Kembel nikada nije izgubio iz vida ideju da čovek jednostavno ne treba da prelazi onu granicu, bez koje on ne bi uopšte bio čovek. Možda ljudi ne treba da žude za visinama, koje nisu za njih. Možda je sreća u filozofiji nepreterivanja.

Kratka priča „Sumrak“ dokazuje da Kembel nije gajio neograničenu veru u naučna dostignuća, iako je antropološki optimizam uoči prvih svemirskih misija bio glavno obeležje Zlatnog doba naučne fantastike. Ovo poglavlje takođe daje uvid u evolucionističke, ali i psihičke i estetske elemente Kembelovog „Sumraka“.

\section{Zaključak}

U ovom delu rada porediće se glavna tumačenja dveju obrađenih priča. To upoređivanje imaće trodelnu strukturu. Najpre će se dotične kratke priče porediti sa aspekta evolucionističke teorije, pri čemu će u fokusu komparacije biti pitanje ljudskog opstanka. Zatim će poređenje biti obavljeno sa aspekta čovekovog unutrašnjeg bića, a taj deo će obuhvatati 
mislilačke (filozofske), duševne (psihičke), kao i duhovne (spiritualne) elemente. Na kraju će uslediti deo o glavnim porukama ovih pripovedaka.

Sa aspekta teorije evolucije, Forsterova priča „Kad mašina stane“ i Kembelov „Sumrak“ imaju jednu suštinski važnu zajedničku tačku. U pitanju je činjenica da u obema pričama uzrok čovečje tragedije leži u pogrešnom shvatanju evolutivnih procesa. Naime, Forsteorova podzemna civilizacija je, kao i Kembelova nadzemna (zapravo se i u „Sumraku“ pominju napuštene podzemne prostorije, ali u ovoj priči malobrojni preostali ljudi žive na površini) u velikoj zabludi kada smatra da se zarad društvenog blagostanja priroda mora prilagoditi čoveku. Međutim, u svetlu evolucionističkih shvatanja, između ove dve distopijske ${ }^{7}$ vizije postoji i izvesna razlika. Naime, dok Forsterova mašinska civilizacija svoj san o eliminaciji svih ugrožavajućih prirodnih činilaca ostvaruje povlačenjem u podzemlje, Kembelovi stanovnici ,utopije“ svoju ,pobedu“ nad prirodom postižu sistematskim uništavanjem neljudskih oblika života na Zemlji. Međutim, ekološka kritika izvodi jasan zaključak da se čovek, baš radi sopstvenog blagostanja, ne sme gorditi nad svojom stvoriteljkom, prirodom. Zatim, „Kad mašina stane“ i Sumrak“ razlikuju se i po pitanju nasleđivanja poraženih civilizacija. Naime, i jedan i drugi pisac nestajućem čovečanstvu ostavljaju izvesnu nadu u opstanak. Međutim, Forster svoje nade polaže u izgnane beskućnike, dok Kembel kao nastavljače čovekove inteligencije na Zemlji vidi mašine ${ }^{8}$.

Kada je reč o duhu žitelja ovih tehnocentričnih „utopija“, treba reći da ovom segmentu posebnu pažnju posvećuju i Forster i Kembel. Sa aspekta duševnosti, uočljive su razlike u načinima na koje Kuno i Kenlin doživljavaju samoću. S jedne strane, Kuno, koji je po rođenju deo mašinskog „prosperiteta“, svoj osećaj samoće predstavlja kao rezultat zanemarivanja telesnosti, međuljudske otuđenosti i intelektualne otupelosti. Forsterov buntovni protagonista zaključuje da je sve to rezultat

7 Možda je pravilnije reći da je reč o antiutopijama a ne distopijama, jer obe civilizacije pokušavaju da stvore raj, ali se njihova tvorevina pretvara u pakao.

8 Ideja da bi čoveka na Zemlji mogle naslediti mašine potiče od Samjuela Batlera. Međutim, u njegovom romanu Edgin [Erewhon] takvo potencijalno nasleđivanje uopšte nema pozitivnih konotacija, za razliku od Kembelove priče „Sumrak“. Zanimljivo je da Batler pominje mogućnost da mašine razviju reproduktivnu sposobnost putem darvinističkog metoda prirodne selekcije, što bi moglo dovesti do toga da surove mašine zagospodare ljudima. 
bezrezervnog poverenja u Mašinu. S druge strane, Kenlin osećaj samoće svojih dalekih potomaka vezuje za opadanje intelektualne radoznalosti i istrebljenje skoro sveukupnog neljudskog živog sveta. Čežnjive pesme tih izgubljenih ljudi na estetski način prikazuju ponižavajuće stanje dekadentnog čovečanstva. Zapravo estetski elementi, koji su u priči „Kad mašina stane" još više prisutni, navode na zaključak da se ova dvojica pisaca razlikuju po svojim pogledima na ljudski rod. Forster čoveka posmatra kao biće koje treba da neguje duhovnu povezanost sa prirodom, ali i ostalim ljudima. Kembel, pak, smatra da je čovek biće koje pomoću svoje inteligencije treba da preuređuje prirodu, ali pri tom preuređivanju često treba da se zapita da li sa sigurnošću može znati kuda ga takva delatnost vodi. Dakle, to što Forsterov estetizam nije usmeren samo na relaciju čovek-priroda, već i na međuljudske odnose, znači da je, za razliku od racionaliste Kembela, engleski književnik bio više okrenut duhovnosti. Kada je u pitanju duhovni deo čovekovog bića, jasno je da su Forsteru bila bliska panteistička shvatanja Baruha Spinoze [Baruch Spinoza, 16321677], ili možda deizam Bendžamina Frenklina [Benjamin Franklin, 17061790]. Činjenica da Kembel, za razliku od Forstera, u svojoj priči o sudbini čovečanstva uopšte ne pominje nikakvo božanstvo ukazuje na to da ovom američkom piscu religijski osećaj nije bio baš blizak. Iz priče „Kad mašina stane“ se, pak, može zaključiti da je Forster verovao u to da neizveštačena, naturistička duhovnost čoveka čini neizmerno bogatim. U pogledu filozofije, neophodno je istaći da postoji velika sličnost između Forsterove i Kembelove priče. Naime, obe priče imaju svrhu da sve one koji radosno kliču sveobuhvatnoj tehnologizaciji podstaknu na razmišljanje o potencijalnom naličju tog procesa. I jedan i drugi pisac posežu za filozofskim relativizmom, kako bi pokazali da mašine treba da budu sluge, a ne gospodari, te da tehnologiju treba razvijati sve dok ona ne počne da čoveka sprečava ,da živi sopstvenom suštinom, koja se zove duša, i drugom suštinom, podjednako božanskom, koja jeste telo" (Forster 1909: 25). Jedina razlika jeste u tome što Forster, veliki poštovalac starogrčke kulture, jasno kaže da suština čovekovog bića počiva u njegovoj prirodnoj telesnosti, dok Kembel samo delimično iznosi tvrdnju da nauka ljudima ne može obezbediti baš sve.

Forster, veliki privrženik estetizma, i Kembel, veliki zagovornik tehnološkog napretka, relativizuju svoje poglede ne bi li postigli isti cilj. Forsterova priča je dirljivija od Kembelove, jer akcenat stavlja na toplinu 
porodice, dok, s druge strane, Kembelova pripovetka sadrži detaljniji opis tehnoloških pojedinosti ${ }^{9}$. Forsterova priča, iz hronoloških razloga, ima izraženiji pionirski karakter. Premda je Kembelova priča podložna dvojakom tumačenju, ipak se čini da preovladava utisak koji se stiče iz njenog naslova. „Sumrak“, reč koja se pojavljuje u obema pričama, neoboriv je dokaz da su obojica autora, doduše možda u nejednakoj meri, nameravala da upozore čitavo čovečanstvo na ono što bi se moglo desiti usled bezobzirne eksploatacije prirodnog okruženja. Sudeći po tome šta se sve događalo nakon 1934. godine, teško je očekivati da će Forsterov strah, a Kembelova opreznost u pogledu tehnološkog napretka ikada postati nerelevantni. S obzirom na to da je savremena civilizacija skoro u potpunosti zasnovana na mehanizaciji i radu digitalnih uređaja, izvesno je da bi ono što ove dve priče poručuju trebalo da bar malo zabrine čoveka današnjice. A te priče nam poručuju da se čovek ne sme poigravati sa svojom planetom, jer se čini krajnje neverovatnim da bi dalje insistiranje na tehnologizaciji moglo ljudima obezbediti da opstanu dovoljno dugo da iza sebe ostave svog naslednika - mašinu, moćniju od entropije. Možda bi ovo zaključno poglavlje trebalo završiti ovako: ubeđenost nekih naučnika da tehnologija može osloboditi čoveka vrlo se lako može završiti potpunim porobljavanjem. Zato bi bilo idealno da mašine budu naše najbolje sluge, da se ne bi jednoga dana pretvorile u veoma zle gospodare.

\section{Literatura}

Abhaya, D. (n.d). „Leaving Home: E. M. Forster and the Pursuit of Higher Values". Western

Buddhist Review: Volume 2. [on-line]. Dostupno preko: http://www.westernbuddhistreview.com/vol2/leaving_home.html [31.07.2014].

9 Inače, Kembel, u odnosu na Forstera, stavlja veći akcenat na nedopustivost čovečjeg intelektualnog nazadovanja. U tom smislu, zanimljiva je činjenica da Kembel, kroz lik Kenlina, ovaj ponižavajući problem oslikava time što zatečenu nesposobnost za inovativnost poredi sa intelektualnom živošću praistorijskog čoveka (kome je od pravljenja kopalja i lovljenja opasnih sabljozubih tigrova zavisio opstanak). Kembel takođe izražava žal što ti dekadentni ljudi nemaju više intelektualnog kapaciteta da iz biljaka, jedinog preostalog neljudskog oblika života, ponovo stvore pokretački duh radoznalosti. 
Anon. 2013: „Fear the Machine: EM Forster's 'The Machine Stops”” (2013). A Study of the Hollow Earth. [on-line]. Dostupno preko: http://thesymzonian.wordpress.com/2013/04/19/fear-the-machineem-forsters-the-machine-stops/ [31.07.2014].

Campbell 1934: John Wood Campbell, „Twilight“. (24-41). [on-line]. Dostupno preko:

http://americanfuturesiup.files.wordpress.com/2013/01/campbelltwilight.pdf [31.07.2014].

D’Ammassa, D. (2005): Encyclopedia of Science Fiction. [on-line]. Dostupno preko: http://www.e-reading.by/bookreader.php/134604/ Encyclopedia_of_Science_Fiction.pdf [02.08.2014].

Đergović-Joksimović, Z. (2009). Utopija: Alternativna istorija. Beograd: Geopoetika.

Forster 1909: Edward Morgan Forster, „The Machine Stops“. (1-25). [online]. Dostupno preko: http://www.ele.uri.edu/faculty/vetter/Otherstuff/The-Machine-Stops.pdf [25.07.2014].

Jonsson, E. (2012): „Man is the Measure: Forster's Evolutionary Conundrum“. (161-176). Style: Volume 46, No. 2. Northern Illinois University, English Department. [on-line]. Dostupno preko: http://gup. ub.gu.se/records/fulltext/163494/163494.pdf [31.07.2014].

Otto, E. (2006): „Science Fiction and the Ecological Conscience“ (PhD Dissertation). University of Florida. [on-line]. Dostupno preko: http://ufdcimages.uflib.ufl.edu/UF/E0/01/34/81/00001/otto_e.pdf [31.07.2014].

Poster, C. (n.d). „Protagoras (fl. $5^{\text {th }}$ C. BCE)“. Internet Encyclopedia of Philosophy. [on-line]. Dostupno preko: http://www.iep.utm.edu/protagor/ [02.08.2014].

Roberts, A. (2006): The History of Science Fiction. Basingstoke, Hampshire (UK): Palgrave MacMillan. [on-line]. Dostupno preko: http:// cla.calpoly.edu/ lcall/303/roberts.pdf [02.08.2014].

Simpson, D. (n.d). „Francis Bacon (1561-1626)“. Internet Encyclopedia of Philosophy. [on-line]. Dostupno preko: http://www.iep.utm.edu/ bacon/ [02.08.2014].

Shovel, M. (ed.) 2007: MacMillan English Dictionary for Advanced Learners: International Student Edition. Second Edition. Oxford: Macmillan Publishers Limited. 
Goran Petrović

\section{Summary \\ TECHNOCRATIC DYSTOPIA IN SF LITERATURE: E.M.FORSTER'S "THE MACHINE STOPS" AND J.W.CAMPBELL'S "TWILIGHT" (A COMPARATIVE PERSPECTIVE)}

This study deals with dystopian visions in early-twentieth-century SF literature. It deals with the following two short stories: E. M. Forster's "The Machine Stops" and J. W. Campbell's "Twilight". The author of this study presents separately critical interpretations of these two works, dealing with Forster's story first and then with Campbell's. The study includes the views of several successful SF scholars. In addition, the above-mentioned views are supplemented by the author's understanding of the stories. The concluding chapter contains a comparison between the two respective anti-utopias. This comparative study brings to the forefront the fact that Forster and Campbell belong to the pioneers of technological dystopia. In ideological terms, the beliefs of environmentalists make the core of this study. These intellectuals support the opinion that, for the sake of mankind's survival, the revitalisation of spiritual naturalism would be the best thing to do. The reason behind this attitude lies in the fact that epistemological anthropocentrism has caused serious pollution of numerous ecosystems. The re-establishment of natural spirituality might create a commonly accepted set of values, which would ultimately prove eco-friendly. Forster, a great devotee of natural aesthetics, and Campbell, an ardent advocate of scientific progress, both assume the stance of relativism in order to tell the whole world that the moderation of technological progress is the only thing that could secure the survival of mankind. While Forster categorically asserts that man is inseparable from nature and other human beings, Campbell only warns that unrestrained technological development might send mankind into the abyss of oblivion. Although Campbell's story could be interpreted as praise for technology, a more probable interpretation of "Twilight" is that the machine, though impervious to entropy, can never be a proper substitute for human beings. In conclusion, under no circumstances should humans tamper with the future of their race, for technology is actually not as omnipotent as it may have seemed at the time of the Industrial Revolution.

Key words: philosophy, dystopia, science, evolution, ecology, anthropocentric, machine, aesthetic, spirituality, technological 